\title{
PENGARUH BEBAN PENJUALAN DISTRIBUSI TERHADAP PENJUALAN BERSIH PADA PERUSAHAAN MANUFAKTUR MAKANAN DAN MINUMAN YANG TERDAFTAR DI BEI PERIODE 2014-2018
}

\author{
Khairaningrum Mulyanti, Ilham Nurdiansyah \\ D4 Akuntansi Keuangan, Politeknik Pos Indonesia Bandung \\ khairaningrum@poltekpos.ac.id, ilhamnurdiansyah71@gmail.com
}

\begin{abstract}
ABSTRAK
Saat ini dunia usaha sudah sangat berkembang dan tingkat persaingan ditiap perusahaan menjadi semakin ketat. Sehingga apabila produk tersebut sedang menjadi kebutuhan konsumen, maka penjualan bersihnya akan meningkat dan pemasaran pun akan bertambah dan menimbulkan beban penjualan distribusi. Tujuan penelitian ini untuk mengetahui beban penjualan distribusi, penjualan bersih, dan pengaruh beban penjualan distribusi terhadap penjualan bersih pada perusahaan manufaktur makanan dan minuman yang terdaftar di BEI periode 2014-2018. Dalam penelitian ini, metode penelitian yang digunakan metode kuantitatif dengan sampel laporan laba rugi pada perusahaan manufaktur yang menjadi objek penelitian. Hipotesis yang ditetapkan uji satu pihak. Metode pemilihan sampel menggunakan menggunakan teknik non probability sampling yakni sampling purposive dan menghasilkan jumlah sampel sebanyak enam perusahaan manufaktur makanan dan minuman yang terdaftar di BEI periode 2014-2018. Teknik analisis yang digunakan korelasi product moment, regresi linier sederhana, koefisien determinasi, dan uji t. Perhitungan statistik menggunakan SPSS for windows 25. Penelitian ini menunjukan bahwa beban penjualan distribusi berpengaruh signifikan terhadap penjualan bersih secara parsial.

Kata Kunci : Beban Penjualan Distribusi, Penjualan Bersih
\end{abstract}

\section{ABSTRACT}

Currently, the business world is very developed and the level of competition in each company is getting tighter. So that if the product is a consumer need, then its net sales will increase and marketing will increase and cause distribution sales expenses. The purpose of this study is to determine the distribution sales expenses, net sales, and the effect of distribution sales expenses on net sales in food and beverage manufacturing companies listed on the IDX for the 2014-2018 period. In this study, the research method used is quantitative methods with a sample of income statements in manufacturing companies that are the object of research. Hypotheses set by one-party test. The sample selection method used a non-probability sampling technique, namely purposive sampling and resulted in a total sample size of six food and beverage manufacturing companies listed on the IDX for the 2014-2018 period. The analysis technique used is product moment correlation, simple linear regression, coefficient of determination, and t test. Statistical calculations using SPSS for windows 25 . This study shows that distribution sales expenses have a significant effect on net sales partially.

Keywords: Distribution Sales Expenses, Net Sales 


\section{PENDAHULUAN}

Saat ini dunia usaha sudah sangat berkembang dan tingkat persaingan ditiap perusahaan menjadi semakin ketat ditambah banyak perusahaan baik makro atau pun mikro yang muncul lalu bergerak dibidang yang sama. Hal itu menjadi pekerjaan rumah yang tidak mudah bagi setiap manajemen perusahaan untuk lebih menarik perhatian konsumen dibanding dengan perusahaan lainnya. Manajemen dituntut untuk mampu mempertahankan eksistensinya dari perusahaan yang mereka jalankan agar konsumen yang ada tidak berpaling terhadap perusahaan lainnya yang sejenis dalam produk.

Dalam melakukan kegiatan distribusi, setiap perusahaan atau khususnya manajemen harus memperhatikan biaya-biaya yang dikeluarkan untuk memasarkan produk tersebut. "Biaya distribusi merupakan biaya-biaya yang dikeluarkan untuk menjual dan membawa produk ke pasar." "Biaya distribusi adalah biaya yang dikeluarkan dari mulai barang selesai dibuat sampai ke tangan konsumen" Mulyadi dalam (Rasyid et all, 2018).

Dikutip dari katadata.co.id pada 1 Juni 2019 yaitu mengenai lesunya konsumsi masyarakat yang memukul kinerja perusahaan konsumer. Dalam berita tersebut dikatan bahwa salah satu penyebab ekonomi tumbuh tidak maksimal adalah melambatnya pertumbuhan konsumsi rumah tangga. Faktor melambatnya tingkat pertumbuhan konsumsi rumah tangga adalah masyarakat menengah keatas yang menahan konsumsinya pada awal tahun. Oleh karena itu Imbas dari konsumsi masyarakat yang tertahan juga dirasakan oleh beberapa emiten atau perusahaan publik yang bergerak disektor konsumer.

Secara garis besar sektor konsumer masih tumbuh, tetapi kinerja beberapa perusahaan khususnya di industri makanan dan minuman cenderung menurun pada awal 2019.

Ditinjau dari laporan keuangan perusahaan manufaktur yang terdaftar di BEI beberapa perusahaan mengalami fluktuasi dalam penjualannya. (S. M. Sari et al., 2018) "Salah satu faktor yang mempengaruhi permintaan dan keinginan konsumen terhadap suatu barang atau jasa adalah faktor selera konsumen, apabila produk yang dipasarkan tersebut sangat sensitif terhadap perubahan selera seperti kualitas atau warna dari suatu produk, hal ini dapat menyebabkan konsumen pindah ke produk lain dengan kualitas dan warna yang menarik dan mutunya lebih tinggi pula".

Penelitian ini mengacu pada penelitian sebelumnya yang pernah dilakukan oleh (Suzan, 2019) yang berjudul "PENGARUH BIAYA PROMOSI DAN BIAYA DISTRIBUSI TERHADAP PENJUALAN (Suatu Studi pada Perusahaan Manufaktur Sektor Food and Beverage yang Terdaftar di Bursa Efek Indonesia 2012-2016)" hasil pengujian regresi data panel dapat diketahui bahwa secara simultan biaya promosi dan biaya distribusi memiliki pengaruh yang signifikan terhadap penjualan perusahaan manufaktur sektor food and beverage yang terdaftari di Bursa Efek Indonesia tahun 20122016.

Pengaruh secara parsial masing-masing variabel terhadap penerimaan penjualan adalah sebagai berikut: a) Biaya promosi memiliki pengaruh yang signifikan dengan arah positif terhadap penjualan perusahaan manufaktur sektor food and beverage yang terdaftari di Bursa Efek Indonesia tahun 2012-2016. Artinya, jika biaya promosi meningkat maka penjualan pun akan ikut meningkat dan EDUTECH CONSULTANT BANDUNG Jurnal AKSARA PUBLIC Volume 2 Nomor 3 Edisi Agustus 2018 (1-11).

Begitu pula sebaliknya, biaya distribusi memiliki pengaruh yang signifikan dengan arah positif terhadap penjualan perusahaan manufaktur sektor food and beverage yang terdaftari di Bursa Efek Indonesia tahun 2012-2016. Artinya, jika biaya distribusi meningkat maka penjualan pun akan ikut meningkat dan begitu pula sebaliknya.

Penelitian selanjutnya yang dilakukan oleh (Yulihartika, 2015) dengan judul "PENGARUH BIAYA DISTRIBUSI TERHADAP JUMLAH PENJUALAN PUPUK PADA PT. PERTANI (PERSERO) CABANG BENGKULU" Hasil analisis peranan 
biaya distribusi fisik dengan volume penjualan pupuk pada PT.Pertani (Persero) cabang bengkulu adalah $Y=68.615+0,446 \mathrm{X}$ yang artinya Segalasesuatu pada variabel-variabel independendianggap konstan yaitu variabel biaya distribusi fisik, maka volume penjualan (Y) adalah sebesar Rp 68.615,-dan jika terjadi penambahan biaya distribusi fisik sebesar Rp 1000,- maka volume penjualan akan meningkat sebesar Rp 4460,-. Dari hasil korelasi (r) diketahui bahwa besarnya korelasi antara volume penjualan dengan biaya distribusi fisik adalah 0,612. Menunjukkan tanda positif berarti berkorelasi positif. Hasil uji T diperoleh $\mathrm{T}$ hitung sebesar 11.366 lebih besar dari Ttabel 1,67 artinya signifikan bahwa biaya distribusi fisik berpengaruh terhadap volume penjualan.

Penelitan selanjutnya yang dilakukan oleh (Asrida, 2015) dengan judul "Pengaruh Biaya Distribusi Dalam Usaha Meningkatkan Volume Penjualan Di Bayu Asri Mesari Grosir" Berdasarkan hasil penelitian, maka dapat disimpulkan sebagai berikut bahwa terdapat pengaruh positif antara distribusi terhadap usaha meningkatkan volume penjualan di Bayu Asri Mesari Grosir. Pengaruh tersebut bersifat signifikan yang berarti perubahan dari biaya distribusiakan merubah nilai dari volume penjualansecara signifikan. Hal tersebut dibuktikan melalui uji korelasi dengan hasil sebesar 0.887.Hal tersebut menyatakan bahwa terjadi korelasi yang kuat antara biaya distribusi (X) terhadap volume penjualan (Y). Selain itu Sesuai hasil perhitungan uji determinasi diperoleh nilai koefisien korelasi adjusted (R2) sebesar 0,765. Hal ini menunjukkan bahwa 23.5\% dari volume penjualan disebabkan oleh distribusi, sedangkan sisa $76.5 \%$ dari volume penjualan disebabkan oleh variabel lain yang tidak diteliti dalam penelitian ini.

Dari latar belakang diatas penelitian ini dilakukan untuk mengetahui apakah terdapat pengaruh antara beban penjualan distribusi dan penjualan bersih pada perusahaan manufaktur makanan dan minuman yang terdaftaar di BEI periode 2014-2018? Terdapat beberapa penelitian terdahulu yang digunakan untuk menjadi referensi penelitian ini yaitu (Yulihartika, 2015) yang berjudul pengaruh biaya distribusi terhadap jumlah penjualan pupuk pada PT.Petani (Persero) cabang bengkulu dan (Asrida, 2015) yang berjudul pengaruh biaya distribusi dalm meningkatkan volume penjualan di Bayu Asri Mesar Grosir.

\section{KAJIAN PUSTAKA \\ Beban Penjualan Distribusi}

Menurut (Hery, 2017) Beban Penjualan adalah beban-beban yang terkait langsung dengan segala aktivitas toko atau aktivitas yang mendukung operasional penjualan barang dagangan, contohnya adalah beban gaji/upah karyawan toko (bagian penjualan), komisi penjualan, beban pengiriman barang, beban iklan, beban perlengkapan/keperluan toko, dan beban penyusutan peralatan toko. "Biaya distribusi adalah biaya yang dikeluarkan dari mulai barang selesai dibuat sampai ke tangan konsumen" Mulyadi dalam ( Rasyid et all, 2018).

\section{Penjualan Bersih}

Penjualan bersih menurut (Mulyadi, 2015) adalah "Penjualan (pada nilai faktur) dikurangi dengan pengembalian, pengurangan harga, biaya transport yang dibayar untuk langganan dan potongan penjualan yang diambil". Berdasarkan sumber tersebut dapat disimpulkan bahwa penjualan bersih merupakan jumlah penjualan yang sudah dikurangi dengan retur penjualan, diskon penjualan dan biaya lainnya.

bersih

\section{METODE PENELITIAN}

Dalam penelitian ini juga menggunakan perumusan masalah yang bersifat asosiatif dengan bentuk hubungan kausal. Menurut (Sugiyono, 2017) "Rumusan masalah assosiatif merupakan suatu rumusan masalah penelitian yang bersifat menanyakan 
hubungan antara dua variabel atau lebih". Sedangkan hubungan kausal menurut (Sugiyono, 2017) adalah hubungan yang bersifat sebab akibat antara variabel independen (variabel yang mempengaruhi) dan variabel dependen (variabel yang dipengaruhi).

\section{Operasionalisasi Variabel}

Operasionalisasi Variabel dapat dilihat pada tabel dibawah ini:

\begin{tabular}{|c|c|c|c|}
\hline Variabel & Indikator & Skala Ukur & Alat Analisis \\
\hline $\begin{array}{l}\text { X: } \\
\text { Beban Penjualan } \\
\text { Distribusi }\end{array}$ & $\begin{array}{l}\text { Jumlah Beban } \\
\text { Denjualan Distribusi } \\
\text { (Mulyadi, 2015) }\end{array}$ & Rasio & $\begin{array}{l}\text { 1. Korelasi product } \\
\text { moment } \\
\text { 2. Regresi Linier } \\
\text { Sederhana } \\
\text { 3. Koefisien } \\
\text { Determinasi } \\
\text { 4. } \mathrm{Uji}^{\mathrm{ji}}\end{array}$ \\
\hline $\begin{array}{l}\text { Y: } \\
\text { Penjualan Bersih }\end{array}$ & $\begin{array}{l}\text { Jumlah Penjualan } \\
\text { Berish } \\
\text { (Mulyadi, 2015) }\end{array}$ & Rasio & $\begin{array}{ll}\text { 1. } & \text { Korelasi Product } \\
\text { Moment } \\
\text { 2. } \\
\text { Regresi Linier } \\
\text { Sederhana } \\
\text { 3. } \text { Koefisien } \\
\text { Determinasi } \\
\text { 4. Uji t }\end{array}$ \\
\hline
\end{tabular}

\section{Teknik Pengumpulan Data}

Metode pengumpulan data merupakan salah satu cara yang digunakan dalam melakukan penelitian. Menurut (Sugiyono, 2017) menyatakan "Metode pengumpulan data dapat dilakukan dengan interview (wawancara), kuesioner (angket), dan observasi (pengamatan)". Metode yang digunakan dalam pengumpulan data dalam ini diperoleh dari Studi dokumentasi, maka data yang diperoleh penulis adalah data sekunder berupa beban penjualan distribusi dan penjualan bersih pada laporan keuangan perusahaan manufaktur makanan dan minuman yang terdaftar di BEI periode 2014-2018 yang diperoleh dari website perusahaan manufaktur makanan dan minuman yang menjadi objek penelitian.

\section{Populasi dan Sampel}

Populasi dalam penelitian ini berupa laporan laba rugi perusahaan manufaktur makanan dan minuman yang terdaftar di BEI Teknik sampel yang digunakan pada penelitian ini adalah nonprobability sampling yakni purposive sampling. Sampel yang digunakan pada penelitian ini adalah sebagai berikut : 1) Periode penelitian yaitu dari tahun 2014 sampai dengan tahun 2018. 2) Jenis data yang digunakan adalah beban penjualan distribusi dan penjualan bersih. 3) Jumlah sampel yang digunakan dalam penelitian ini sebanyak 30 sampel.

\section{Teknik Analisis Data}

Teknik analisis data yang digunakan dalam penelitian ini adalah Korelasi Product Moment, regresi linier sederhana, Koefisien Determinasi, Uji t.

\section{HASIL DAN PEMBAHASAN}

Uji Korelasi Product Moment 
Tabel 1. Hasil Korelasi Product Moment

\begin{tabular}{|c|c|c|c|}
\hline \multicolumn{4}{|c|}{ Correlations } \\
\hline & & $\begin{array}{c}\text { Beban_Penju } \\
\text { alan_Distrbu } \\
\text { si }\end{array}$ & $\begin{array}{c}\text { Penjualan_B } \\
\text { ersih }\end{array}$ \\
\hline \multirow{3}{*}{$\begin{array}{l}\text { Beban_Penjualan_Distrb } \\
\text { usi }\end{array}$} & Pearson Correlation & 1 & $.938^{\mathrm{Nx}}$ \\
\hline & Sig. (2-tailed) & & .000 \\
\hline & $N$ & 30 & 30 \\
\hline \multirow[t]{3}{*}{ Penjualan_Bersih } & Pearson Correlation & $.938^{\star \star}$ & 1 \\
\hline & Sig. (2-tailed) & .000 & \\
\hline & $\mathrm{N}$ & 30 & 30 \\
\hline
\end{tabular}

Sumber : Data Diolah penulis

Berdasarkan hasil data diatas bahwa nilai korelasi product moment variabel beban penjualan distirbusi $(\mathrm{X})$ terhadap variabel penjualan bersih $(\mathrm{Y})$ adalah 0,938. Angka korelasi menunjukan bahwa korelasi antara beban penjualan distirbusi (X) dengan penjualan bersih $(\mathrm{Y})$ berada dalam kategori "Sangat Kuat" sesuai dengan pedoman interpretasi korelasi product moment dengan nilai antara 0,800-0,1.000, kemudian signifikasi yang menyertainya ternyata lebih kecil dari $0,05(0,000<0,05)$ apabila seperti itu tandanya positif. Artinya jika variabel $(\mathrm{X})$ meningkat maka akan meningkat juga variabel (Y). Itu berarti korelasi yang terjadi dalam kategori sangat kuat.

\section{Regresi Linier Sederhana}

Analisis regresi digunakan untuk memprediksikan seberapa jauh perubahan nilai variabel dependen, bila nilai variabel independen dimanipulasi/dirubah-rubah atau dinaikturunkan, regresi sederhana didasarkan pada hubungan fungsional ataupun kausal satu variable independen dengan satu variable dependen.

\section{Tabel 2. Hasil Regresi Linier Sederhana}

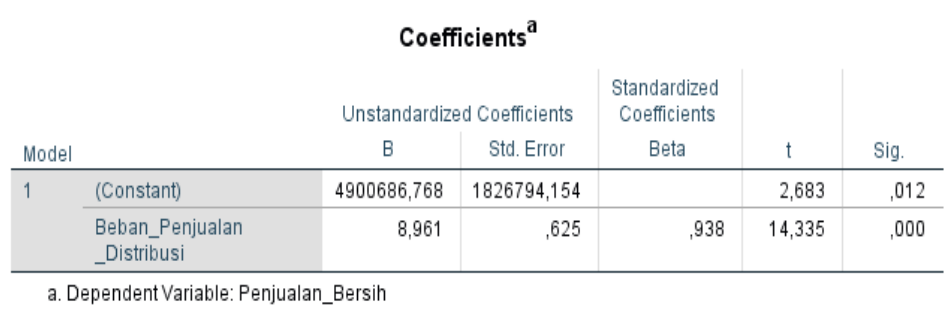

Sumber: Data Diolah Penulis

ini:

Dari hasil output pengolahan data diatas, maka dapat persamaan seperti dibawah

\section{$Y=4900686,768+8,961 X$}

1. Jika variabel $(\mathrm{X})$ beban penjualan distibusi nilainya adalah 0 , maka nilai variable $(\mathrm{Y})$ penjualan bersih adalah sebesar konstanta atau sebesar 4900686,768.

2. Koefisien regresi dari variabel $X$ yaitu beban penjualan distibusi sebesar 8,961 artinya dimana jika variabel independent lain nilainya tetap dan beban penjualan distribusi mengalami kenaikan Rp. 1, maka penjualan bersih sebagai variabel dependen akan mengalami kenaikan sebesar Rp.8,961. Karena koefisien X bernilai positif maka terjadi hubungan positif pula antara beban penjualan distibusi (X) terhadap penjualan bersih $(\mathrm{Y})$, jadi kenaikan beban penjualan distribusi $(\mathrm{X})$ mengakibatkan kenaikan juga pada penjualan bersih (Y).

\section{Koefisien Determinasi}


Koefisien determinasi dihitung dengan mengkuadratkan koefisien korelasi yang telah ditentukan, data selanjutnya dikaitkan dengan 100\%. Koefisien determinasi (penentu) dinyatakan dalam persen.

\section{Tabel 3. Hasil Koefisien Determinasi}

\begin{tabular}{|c|c|c|c|c|}
\hline \multicolumn{5}{|c|}{ Model Summary } \\
\hline Model & $\mathrm{R}$ & R Square & $\begin{array}{l}\text { Adjusted R } \\
\text { Square }\end{array}$ & $\begin{array}{l}\text { Std. Error of } \\
\text { the Estimate }\end{array}$ \\
\hline 1 & $938^{\mathrm{a}}$ & 880 & 876 & 8551582,642 \\
\hline
\end{tabular}

Sumber : Data Diolah Penulis

Dapat diketahui nilai $\mathrm{R}^{2}$ sebesar 0,880 yang artinya persentase pengaruh variabel independent yaitu beban penjualan distribusi (X) terhadap variabel dependen yaitu penjualan bersih (Y) sebesar $88 \%$ dan sisanya $12 \%$ dipengaruhi oleh variabel lain yang tidak dimasukkan kedalam penelitian ini.

\section{Pengujian Hipotesis ( Uji t)}

Uji t digunakan untuk menguji signifikasi hubungan, yaitu apakah hubungan yang ditemukan berlaku untuk seluruh populasi, maka perlu diuji signifikansinya”. Uji t dalam penelitian ini digunakan untuk mengetahui apakah variabel independen (Biaya Pemasaran (X)) secara parsial mempunyai pengaruh yang signifikan terhadap variabel dependen (Volume Penjualan (Y)).

\section{Tabel 4. Hasil Uji T}

\begin{tabular}{|c|c|c|c|c|c|c|}
\hline \multicolumn{7}{|c|}{ Coefficients $^{a}$} \\
\hline \multirow[b]{2}{*}{ Model } & & \multicolumn{2}{|c|}{ Unstandardized Coefficients } & \multirow{2}{*}{$\begin{array}{c}\text { Standardized } \\
\text { Coefficients } \\
\text { Beta } \\
\end{array}$} & \multirow[b]{2}{*}{$t$} & \multirow[b]{2}{*}{ Sig. } \\
\hline & & B & Std. Error & & & \\
\hline \multirow[t]{2}{*}{1} & (Constant) & 4900686,768 & 1826794,154 & & 2,683 &, 012 \\
\hline & $\begin{array}{l}\text { Beban_Penjualan } \\
\text { _Distribusi }\end{array}$ & 8,961 &, 625 & .938 & 14,335 &, 000 \\
\hline
\end{tabular}

Sumber : Data Diolah Penulis

Hasil pengujian beban penjualan distribusi terhadap penjualan bersih menunjukkan $t_{\text {hitung }}$ yang diperoleh sebesar 14,335 dan signifikansi $0,000, t_{\text {tabel }}$ dapat dilihat pada tabel statistik. Pada signifikansi 0,05 dengan derajat kebebasan dk pembilang $=1$, dk penyebut $=29(n-k-1)$, dimana $n=j u m l a h$ data, $\mathrm{k}=$ jumlah variabel $\mathrm{x}$, hasil diperoleh untuk $t_{\text {tabel }}$ sebesar 2,045. Nilai $t_{\text {hitung }}>t_{\text {tabel }}(14,335>2,045)$ dan signifikansi $<0,05$ $(0,000<0,05)$ maka Ha diterima dan Ho ditolak, itu berarti ada pengaruh yang positif antara beban penjualan distribusi terhadap penjualan bersih.

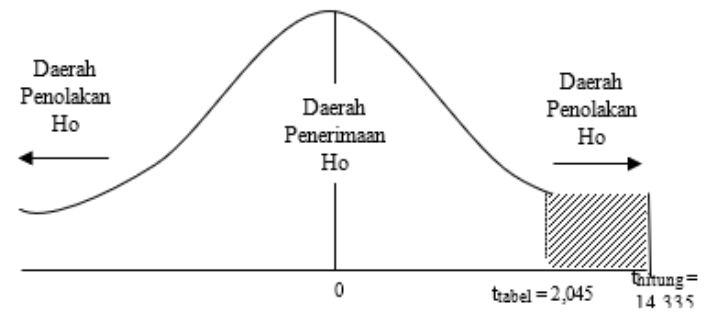

Kurva Distribusi X terhadap Y 
Pada gambar diatas dapat dilihat nilai $t_{\text {hitung }}$ sebesar 14,335 jatuh pada penerimaan Ha, sehingga dapat disimpulkan bahwa terdapat pengaruh yang signifikan antara beban penjualan distribusi terdapat terhadap penjualan bersih pada perusahaan manufaktur makanan dan minuman yang terdaftar di BEI periode 2014-2018.

\section{PEMBAHASAN}

\section{Beban Penjualan Disitribusi pada Perusahaan Manufaktur Makanan dan Minuman} yang terdaftar di BEI Periode 2014-2018

Perkembangan beban penjualan distribusi pada perusahaan Perusahaan manufaktur makanan dan minuman yang terdaftar di BEI periode 2014-2018, dari 6 perusahaan yang menjadi objek penelitian mengalami kenaikan atau penurunan baik dalam biaya pemasaran. Daftar beban penjualan distribusi tertinggi tahun 2018 pada PT. Indofood Sukses makmur Tbk. Sebesar 7.817.444 (dalam bentuk jutaan) dan untuk daftar beban penjualan distribusi terendah ada pada PT. Akasha Wira International Tbk. Tahun 2014 sebesar 170.138 ( disajikan dalm bentuk jutaan).

\section{Penjualan Bersih pada Perusahaan Manufaktur Makanan dan Minuman yang terdaftar di BEI Periode 2014-2018.}

Perkembangan penjualan bersih pada perusahaan Perusahaan manufaktur makanan dan minuman yang terdaftar di BEI periode 2014-2018, dari 6 perusahaan yang menjadi objek penelitian mengalami kenaikan atau penurunan pada beberapa perusahaan di tahun 2018 terjadi penurunan dalam penjualan bersih itu terjadi akibat adanya konsumi yang tertahan dimasyarakat yang berakibat pada menurunya penjualan bersih di perusahaan manufaktur makanan dan minuman dan itu tidak sesuai dengan harapan perusahaan.

Menurut (Mulyadi, 2015), mendefinisikan bahwa "Penjualan merupakan kegiatan yang dilakukan oleh penjual dalam menjual barang atau jasa dengan harapan akan memperoleh laba dari adanya transaksi-transaksi tersebut dan penjualan dapat diartikan sebagai pengalihan atau pemindahan hak kepemilikan atas barang atau jasa dari pihak penjual ke pembeli".

\section{Pengaruh Beban Penjualan Distribusi Terhadap Penjualan Bersih}

Hasil dari perhitungan menggunakan program SPSS Statistics versi 25.0 analisis product moment korelasi antara beban penjualan distribusi (X) terhadap penjualan bersih (Y) menghasilkan nilai $\mathrm{r}$ dalam angka sebesar 0,938 yang dimana artinya memiliki hubungan yang sangat kuat. Serta hasil dari analisis regresi linier sederhana dari variabel $\mathrm{X}$ yaitu beban penjualan distribusi sebesar 8,961 artinya dimana jika variabel independent lain nilainya tetap dan beban penjualan distribusi mengalami kenaikan Rp. 1, maka penjualan bersih sebagai variabel dependen akan mengalami kenaikan sebesar Rp.8,961.

Hasil koefisien determinasi bahwa nilai $\mathrm{R}^{2}$ sebesar 0,880 yang artinya persentase pengaruh variabel independent yaitu beban penjualan distribusi (X) terhadap variabel dependen yaitu penjualan bersih (Y) sebesar $88 \%$ dan sisanya $12 \%$ dipengaruhi oleh variabel lain.

Uji secara parsial variabel beban penjualan distribusi mempunyai thitung sebesar 14,335 dan $t_{\text {tabel }}$ sebesar 2,045 yang berarti $t_{\text {hitung }}>t_{\text {tabel }}$ dan angka signifikansinya sebesar 0,000 yang berada dibawah signifikansi 0,05 . Maka dapat disimpulkan bahwa hipotesis Ha diterima dan Ho ditolak, yang artinya diduga terdapat pengaruh yang signifikan antara beban penjualan distribusi terhadap penjualan bersih pada perusahaan manufaktur makanan dan minuman yang terdaftar di BEI periode 2014-2018. Menurut Swastha dalam (Saragih, 2017) "Volume penjualan merupakan penjualan bersih dari laporan laba perusahaan. Penjualan bersih diperoleh melalui hasil penjualan seluruh produk (produk lini) selama jangka tertentu, dan hasil penjualan yang diperoleh dari market share (pangsa pasar) yang merupakan penjualan potensial, yang dapat terdiri dari kelompok teritorial dan kelompok pembeli saham jangka waktu tertentu". 
Berdasarkan variabel diatas yaitu beban penjualan distribusi akan berpengaruh terhadap penjualan bersih pada perusahaan manufaktur makanan dan minuman yang terdaftar di (BEI). Seperti halnya penelitian sebelumnya yang dilakukan oleh Yulihartika (2015) biaya distribusi fisik berpengaruh terhadap volume penjualan yang berarti variabel biaya distribusi fisik berpengaruh signifikan terhadap variabel volume penjualan, dengan kata lain jika volume penjualan meningkat maka biaya distribusi fisik juga meningkat.

\section{KESIMPULAN}

\section{SIMPULAN}

Berdasarkan identifikasi masalah, hipotesis dan hasil pengujian yang telah dilakukan untuk mengtahui bagaimana beban penjualan distribusi terhadap penjualan bersih pada perusahaan manufaktur makanan dan minuman yang terdaftar di BEI periode 2014-2018, maka dapat disimpulkan sebagai berikut:

1. Perkembangan beban penjualan distribusi mengalami kenaikan dan penurunan disetiap tahunnya, ada yang menunjukkan kenaikan dan penuruannya. Dari hasil output SPSS regresi linier sederhana untuk variabel biaya pemasaran sebesar 8.961 dari analisis regersi linier sederhana tersebut adalah positif yang artinya jika beban penjualan distribusi mengalami kenaikan, maka penjualan bersih akan mengalami kenaikan juga.

2. Perkembangan penjualan bersih disetiap tahunnya mengalami penaikan dan penurunan, ada yang menunjukkan kenaikan dan penuruannya signifikan adapun yang tidak signifikan. Akibat adanya konsumsi yang tertahan dimasyarakat yang berakibat pada menurunya penjualan bersih di perusahaan manufaktur makanan dan minuman.

3. Hasil uji hipotesis secara parsial antara variabel (X) beban penjualan distribusi terhadap variabel $(\mathrm{Y})$ penjualan bersih menunjukkan bahwa hipotesis Ha diterima dan Ho ditolak, yang artinya diduga terdapat pengaruh yang signifikan antara beban penjualan distribusi terhadap penjualan bersih pada perusahaan manufaktur makanan dan minuman yang terdaftar di BEI periode 2014-2018.

\section{SARAN}

Berdasarkan kesimpulan diatas, penulis mencoba memberikan saran yang dapat memberikan manfaat bagi peneliti selanjutnya. Adapun saran tersebut adalah sebagai berikut:

1. Peneliti selanjutnya yang tertarik untuk meneliti lebih lanjut dengan tema yang sama yaitu Akuntansi Biaya, disarankan untuk memperbaiki kekurangan-kekurangan yang terdapat didalam penelitian ini.

2. Penelitian selanjutnya diharapkan dapat menambahkan sampel yang digunakan dan memperluas penelitian bukan hanya 6 perusahaan saja sehingga hasil data yang lebih baik.

3. Bagi peneliti selanjutnya yang akan melakukan penelitian selanjutnya, penulis menyarankan agar peneliti dapat menambahkan atau merubah Variabel Y (Dependen) lagi selain penjualan bersih untuk lebih mengetahui variabel $\mathrm{Y}$ lain yang dapat dipengaruhi oleh beban penjualan distribusi.

\section{DAFTAR PUSTAKA}

Asrida. (2015) Pengaruh Biaya Distribusi Dalam Usaha Meningkatkan Volume Penjualan Di Bayu Asri Mesari Grosir Vol.3 No.1 Februari 2015

Bursa Efek Indonesia (https://www.idx.co.id/perusahaan-tercatat/laporan-keuangan-dantahunan/ diakses 2 mei 2020)

Lanen, W. N., Anderson, S. W., \& Maher, M. W. (2017). Dasar-dasar akuntansi biaya (Edisi $4 \mathrm{Bu}$ ). Salemba Empat

Mulyadi. (2015). Akuntansi Biaya. Sekolah Tinggi Ilmu Manajemen YKPN. 
PT. Indofood Sukses Makmur Tbk. (https://www.indofood.com/company/indofood-at-aglance/ diakses 28 Juni 2020)

PT. Tiga Pilar Sejahtera Food Tbk. (https://tpsfood.id/our-company/tentang-kami/ diakses 28 Juni 2020)

PT.Multi Bintang Indonesia Tbk (https://www.multibintang.co.id/id/company/companyprofile/ diakses 28 Juni 2020)

PT. Akasha Wira International Tbk. (https://www.akashainternational.com/id_ID/ourprofile/ diakses 28 Juni 2020) PT. Tunas Baru Lampung Tbk. (https://www.tunasbarulampung.com/company/ diakses 28 Juni 2020)

PT. Japfa Comfeed Indonesia Tbk. https://www.japfacomfeed.co.id/id/about-us/visionmission-values/diakses 28 Juni 2020)

Rasyid, A. dan, suzan,L. (2018) Pengaruh Biaya Promosi dan iaya distribusi terhadap Penjualan (suatu studi perusahaan manufaktur Sektor food and Beverage yang terdaftar di Bursa Efek indonesia 2012-2016)

saragih, h. (2017). 149 jurnal ilmiah methonomi vol. 3 no. 2 (juli-desember 2017). 3(2).

sari, i., rifa, a., dan, m., program, d., administrasi, s., \& fisipol, b. (2018). analisis faktorfaktor yang mempengaruhi volume penjualan sepeda motor yamaha jupiter $z$ pada $t$ . alfa scorpii pekanbaru. 1-22.

sugiyono. (2017). metode kuantitatif, kualitatif dan $r \& d$. alfabeta.

yulihartika.(2015).pengaruhbiaya distribusi terhadap jumlah penjualan pupuk pada pt. pertani (persero) cabang bengkulu (Juli-Desember 2015). 